INSTITUTE OF FORESTRY • BELGRADE

INSTITUT ZA ŠUMARSTVO • BEOGRAD

SUSTAINABLE FORESTRY

COLLECTION 69-70, 2014
ODRŽIVO ŠUMARSTVO

ZBORNIK RADOVA 69-70, 2014

UDK 630*145.78 Lymantria dispar L.+630*4(497.11-751.2 Đerdap)“1996/2014“=111 Original scientific paper

\title{
THE OUTBREAKS OF THE GYPSY MOTH IN THE FORESTS OF NATIONAL PARK ĐERDAP IN THE PERIOD FROM 1996 TO 2014
}

\author{
Mara TABAKOVIĆ-TOŠIĆ ${ }^{l}$, Marija MILOSAVLJEVIĆ ${ }^{2}$, Nemanja SIMOVIĆ
}

\begin{abstract}
This paper presents the results of the study of the population levels of the gypsy moth in the forests of National Park Đerdap, over the period 1996-2014. The characteristics of three outbreaks (1996-1997, 2003-2005 and 2009-2014) of the gradogenic character were studied. Since these are forest ecosystems of the natural protected areas in which the special rules and measures aimed at the protection from the adverse effect of the wide range of the biotic and abiotic factors are applied, with the special emphasis on the possible, or impossible, use of pesticides, the paper also analyzes the control measures which were taken, i.e. the reduction of the density of the gypsy moth to the normal population level. In addition, the effect of two species of egg parasitoids, as well as of Entomophaga maimaiga and Lymantria dispar multicapsid nuclear polyhedrosis virus (LdMNPV) - pathogenic worms, on the population level of the gypsy moth in some years of the outbreak was studied.
\end{abstract} enemies.

Key words: Lymantria dispar, outbreak, natural protected area, control, natural

\section{PRENAMNOŽENJA GUBARA U ŠUMSKIM KOMPLEKSIMA NACIONALNOG PARKA ĐERDAP U PERIODU OD 1996. DO 2014. GODINE}

Abstract: $U$ radu su prikazani rezultati istraživanja visine populacionih nivoa gubara u šumskom području Nacionalnog parka Đerdap, u periodu 1996-2014. godina.

\footnotetext{
${ }^{1}$ Ph.D. Mara Tabaković-Tošić, Senior Research Fellow, Institute of Forestry, Belgrade

${ }^{2}$ Marija Milosavljević, M.Sc. and Student of Doctoral Studies of the Faculty of Biology at the University of Belgrade

${ }^{3}$ Nemanja Simović, Student of Doctoral Studies of the Faculty of Forestry at the University of Belgrade

Translation: Marija Stojanović
} 
Analizirane su karakteristike tri prenamnoženja (1996-1997., 2003-2005. i 2009-2014. godina) gradogenog karaktera. Kako se radi o šumskim ekosistemima zaštićenog prirodnog dobra u kojima se primenjuju posebna pravila i mere zaštite od negativnog dejstva čitavog kompleksa biotičkih i abiotičkih faktora, s posebnim osvrtom na moguću, ili nemoguću, upotrebu pesticida, u radu su analizirane i preduzete mere suzbijana, odnosno svođenja brojnosti gubara na normalni populacioni nivo. Takođe, istražen je uticaj dve vrste jajnih parazitoida, te Entomophaga maimaiga $i$ Lymantria dispar multicapsid nuclear polyhedrosis virus (LdMNPV) - patogeni larvi, na populacioni nivo gubara u pojedinim godinama prenamnoženja.

Ključne reči: Lymantria dispar, gradacija, zaštićeno prirodno dobro, suzbijanje, prirodni neprijatelji

\section{INTRODUCTION}

The gypsy moth (Lymantria dispar L.), insect from the order Lepidoptera, is one of most dangerous pests of broadleaf forests and orchards. It is characterised by a high reproductive capacity, considerable ecological plasticity and polyphagia. Although it is found on four continents (North Africa, Asia, Europe, North America), the greatest damage is caused to the forests of the Balkan Peninsula, which have all favourable environmental conditions for the gypsy moth development.

The abundance, i.e. the population level of the gypsy moth is conditioned by the characteristics of the species, physiological conditions of some instars, as well as by the biotic and abiotic factors, such as weather conditions, type and quality of host plants, pathogens, natural enemies (Milanović et al., 2006; Tabaković-Tošić, 2011, 2012; Tabaković-Tošić et al., 2013).

In the forests of the Republic of Serbia gypsy moth is the outbreaking species, and the periodical outbreaks most frequently occured in the middle-aged oak and beech stands, since in the younger or older ones, the calamity is the result of the migration of the caterpillars in the search for food.

The oak forests in the National Park Đerpad, regarding the intensity of the multi-annual desiccation of the broadleaf forests of the Balkans Peninsula, is the most endangered area in Serbia. In some years the volume of the desiccated tree was 2-3-fold greater than the current volume increment of some tree species (Marinković, 1992). It should be taken into account that the defoliation caused by the nutrition of the gypsy moth lead to the loss in the increment, lack of the seed production, physiological weakening and desiccation of trees, as well as to the creation of the conditions favourable to the attack of the phytopathogenic microorganisms, fungi and xylophagous insects. In the forests after the defoliation by the gypsy moth the other adverse factors are interconnected so on the newlyformed leaves, during the summer months, powdery mildew occurs almost regularly (Erysiphe alphitoides, Griffon \& Maublanc), which leads to the premature desiccation and loss of the newly-formed shots, which is the additional stress for the plant. The defoliation of the gypsy moth enables the plenty of the suitable material for the outbreak of the European oak bark beetle (Scolytus inticatus Ratz.), thereby the possibility for the formation of the infections by the 
fungi from genus Ophiostoma is greater. Taking all these facts into account, it becomes clearer how great is the importance of the gypsy moth and the periodic outbreaks of it in the above-mentioned decay of the forests.

\section{AREA OF RESEARCH}

The National Park Đerdap is located in the northeastern part of the Republic of Serbia, in the Carpathian Mountains and encompasses the following coordinates: $44^{\circ} 42^{\prime} 50^{\prime \prime} \mathrm{N}$ and $21^{\circ} 40^{\prime} 40^{\prime \prime}-22^{\circ} 33^{\prime} 10^{\prime \prime} \mathrm{E}$. The area of the National Park $(63,608$ hectares $)$ is located in the territory of Golubac $(18,116.55$ hectares $)$, Majdanpek (29,467.15 hectares) and Kladovo (16,024.75 hectares), within 16 cadastral municipalities (Golubac, Brnjica, Dobra, Boljetin, Donji Milanovac, Majdanpek, Mosna, Topolnica, Golubinje, Miroč, Tekija, Petrovo Selo, Sip, Davidovac, Kladušnica, Podvrška) and covers the tight hilly-mountain zone (50 800 meters above the sea level), $2-8 \mathrm{~km}$ wide, on the right bank of the Danube River.

Based on the climate regions of Serbia, the National Park Đerdap is located in the climate region III where the modified continental climate is dominant. For the analysis of the air temperature there are data of the weather stations in Veliko Gradište, Tekija, Karataš, Brza Palanka ans Turn Severin, as well as the data presented in the maps of the Climate Atlas of the Former Yugoslavia. In the abovementioned weather stations the air temperatures higher than $20^{\circ} \mathrm{C}$ occur in July and August, and in Veliko Gradište and Turn Severin in June as well. The lowest mean monthly air temperature in all the stations is in January. In the riparian zone of Đerdap Lake it is $-1^{\circ} \mathrm{C}$, and in the highest parts of the National Park Đerdap it is about $-4^{\circ} \mathrm{C}$. The mean air temperature in the warm half of the year is $18^{\circ} \mathrm{C}$. The air temperatures higher than $5^{\circ} \mathrm{C}$ occur in 240 to 260 days a year. In the riparian zone of Đerdap Lake there are 180 days with the temperature higher than $10^{\circ} \mathrm{C}$, and in the higher parts of the National Park Đerdap about 170 days. The number of days with the air temperature higher than $15^{\circ} \mathrm{C}$ ranges from 120 to 160 and it refers to the summer season. There are 100 hot (summer) days with the air temperatures higher than $25^{\circ} \mathrm{C}$ in the lower parts of the National Park Đerdap, and 50 in the highest part of it. The number of tropical days in which the year temperature is higher than $30^{\circ} \mathrm{C}$ in the riparian zone of the lake is 30 , and in the higher parts it is 20 (Stanković, 2003).

The relative air humidity in the National Park Đerdap is increased, due to the great area of Đerdap Lake and considerable percentage of the forest areas. It is highest in December, and lowest in August. The increased air humidity leads to the lowest levels of insolation (Stanković, 2003).

The current data on the pluviometrics regime points to the fact that the National Park Đerdap gains from 200 to $300 \mathrm{~mm}$ precipitation less than the average value for Serbia and Montenegro. The precipitation is most frequent in May and June, and it is least frequent in August and September. The first snow occurs in mid-December, and the last in early April. The average depth of the snow around Đerdap Lake ranges from 30 to $40 \mathrm{~cm}$, and in the higher parts it is $60 \mathrm{~cm}$. The snow deeper than $10 \mathrm{~cm}$ lasts from 20 to 40 days per a year. The snow $30 \mathrm{~cm}$ deep in the lowest part of the National Park Đerdap lasts for only 5 days a year, and in 
the highest part for 20 days. The snow $50 \mathrm{~cm}$ deep is a rare phenomenon and lasts from 6 to 10 days per a year. The strongest and most frequent wind in the National Park Đerdap is košava. It occurs in the winter season (Stanković, 2003).

Based on the biogeographical position, the area of Đerdap is located at the border of two floristic regions: Middle European or region of broadleaf forests and Pontic-South Siberian or steppe-forest-steppe region (Stevanović, 1996).

The basic vegetation cover of the Đerdap area of the Danube River, and particularly of the National Park Đerdap, is the forest. The forest phytocoenoses are characterised by the stability and high level of the regeneration, which implies that the environmental conditions are favourable. The National Park Đerdap is characterised by the great complexity and diversity of the forest and accompanying bushy vegetation, as well as by the well-expressed differences in the plant species on the lime and silicate rocks, as well as the differences in the vegetation of gorges and ravines. Forests account for $70 \%$ of the total area of the National Park, and $83 \%$ are privately-owned (Medarević, M., 2001). In the National Park Đerdap forty autochtonous tree species were reported. The most frequent ones are the beech $(63.3 \%)$ and sessile oak (18.4\%), followed by the European hornbeam (5.5\%) and the lime tree $(2.4 \%)$. The oak stands are the special value of the area of the National Park. They are most frequently ripening, ripe and overripe, and account for $7.0 \%$ of the total area of the state-owned forests ( Medarević, 2001). It is the result of the continental climate and peculiar edaphic stand conditions, particularly of the slope of the terrain and exposure.

\section{MATERIAL AND METHOD}

\subsection{Monitoring of the population level of the gypsy moth}

Every year in all broadleaf forests (during the outbreak in the conifer as well), regardless of the category of the ownership (state and private), and based by the Prescriptions by the Operators of the reporting-diagnostics-forecast activities in the domain of the plant protection - forest protection, the population level of it was monitored. The monitoring of population level of the gypsy moth in the forests was conducted by using the methods of the permanent $(25 \times 25 \mathrm{~m})$ and temporary $(10 \times 10$ m) sample plots, as well as by using the route method.

The accurate determination of the intensity of the attack and spatial definition of the attacked areas are very important, since these are the key factors for the selection of methods and time of the control: in the egg instar (mechanically or chemically in the period of the leaf fall in autumn, until the beginning of the breaking into leaf in spring) or the larval instar (aerial spraying which is performed in the late April or early May).

The permanent sample plots were monitored every year, and the temporary ones were monitored when it was estimated that there was a risk of the outbreak. The route method was applied as the supplement when the gypsy moth was in the latency phase (low population level), and was obligatory used in the time of the outbreak (Tabaković-Tošić, 2002). 


\subsection{Quantitative and qualitative analysis of the gypsy moth egg masses}

The detailed quantitative and qualitative analysis of the sampled egg masses were conducted in the laboratory of the Institute of Forestry, and depending on the observed parameter, either ocular or the method of the survey by the binocular magnifier was applied. In addition, under the laboratory conditions in the winter period the dynamics of the hatching of imagos of the parasitoids of the gypsy moth eggs from the previosly observed egg masses was monitored. Out of each egg mass a total 100 of the randomly sampled, previously cleaned eggs was placed in the specially prepared test tubes (with the distilled water on the bottom and cotton pads in the middle, in order to prevent the eggs from being soaked). The test tubes with the sampled gypsy moth eggs were kept in the climate chamber. During the experiment, the air temperature and light regime were constant (temperature $19^{\circ} \mathrm{C}$, light regime 10 hours by night, 14 hours by daytime )

\subsection{Microscopic analysis of the dead gypsy moth caterpillars - detection of the presence of LdMNPV and Entomophaga maimaiga Humber, Shimazu \& R.S. Soper}

From all sites, in the summer and autumn of the period 2010-2014, dead gypsy moth larvae were collected for different laboratory analyses. Each study plot was 1 ha in size and included a minimum of 25 trees. Gypsy moth dead caterpillars were collected manually from foliage in the lower parts of tree crowns and tree branches and trunk, two to three times per year.

Microscopic (magnification 1200 times) analyses of some dead gypsy moth larvae with characteristic symptoms caused by the $L d M N P V$ was conducted immediately using the standard method of Giemsa's differential staining.

The dead larvae with characteristic symptoms caused by the entomopathogenic fungus E. maimaiga were also placed in Petri dishes and the detailed microscope survey of the dead gypsy moth caterpillars was done later. The evaluation of E. maimaiga infections was recorded as positive when azygospores and conidiospores were detected in the cadavers of dead gypsy moth larvae. The species identification was based on the size, shape and structural characteristics of different life forms of the fungus - azygospores, conidiospores and mycelia.

\section{RESULTS AND DISCUSSION}

In the area of the National Park Đerdap, after the thirty-year period of latency, the significant growth of the gypsy moth population level occurred.

During these studies, when the number of the gypsy moth egg masses per a unit of area (1 hectare) was determined, the attention was paid so that all forest plantations would be encompassed. It is of a special importance for the areas where the attack of a very strong intensity (more than 500 egg masses per a hectare) was reported, since the damages expressed by the damage of the foliage which will be caused by the hatched larvae, are not the same in the case when 501 egg masses 
attack per a hectare and when, for instance, 50,000 egg masses attack per a hectare (Tabaković-Tošić, 2005-2006).

Table 1 Spread of the gypsy moth in the forests of the National Park Đerdap over the period 1996-2014 (egg masses hatched in the late summer season).

\begin{tabular}{|c|c|c|c|c|c|c|c|c|c|}
\hline \multirow{3}{*}{ YEAR } & \multicolumn{9}{|c|}{ INTENSITY OF ATTACK AND THE ATTACKED AREA } \\
\hline & \multicolumn{2}{|c|}{$\begin{array}{c}\text { Weak } \\
1-10 \text { egg } \\
\text { masses/hectare }\end{array}$} & \multicolumn{2}{|c|}{$\begin{array}{c}\text { Moderate } 11-100 \text { egg } \\
\text { masses/hectare }\end{array}$} & \multicolumn{2}{|c|}{$\begin{array}{l}\text { Strong 101-500 egg } \\
\text { masses/hectare }\end{array}$} & \multicolumn{2}{|c|}{$\begin{array}{c}\text { Very strong } \\
\text { more than } 500 \text { egg } \\
\text { masses/hectare }\end{array}$} & \multirow[t]{2}{*}{ TOTAL } \\
\hline & ha & $\%$ & ha & $\%$ & ha & $\%$ & ha & $\%$ & \\
\hline 1996 & 0 & 0 & 127.0 & 29.7 & 301.0 & 70.3 & 0 & 0 & 1428.0 \\
\hline 1997 & 17739.0 & 56.3 & 10155.0 & 32.2 & 0 & 0 & 3643.0 & 11.5 & $\mathbf{3 1 5 3 7 . 0}$ \\
\hline \multicolumn{10}{|c|}{ 1998-2002 - latency period for the gypsy moth } \\
\hline 2003 & 10947.0 & 93.2 & 801.0 & 6.8 & 0 & 0 & 0 & 0 & 11748.0 \\
\hline 2004 & 7599.0 & 76.0 & 1307.0 & 13.1 & 186.0 & 1.9 & 900.0 & 9.0 & 9992.0 \\
\hline 2005 & 968.8 & 5.8 & 1924.0 & 11.5 & 4071.2 & 24.2 & 9803.3 & 58.5 & 16767.4 \\
\hline \multicolumn{10}{|c|}{ 2006-2009 -latency period for the gypsy moth } \\
\hline 2010 & \multirow{2}{*}{\multicolumn{9}{|c|}{$\begin{array}{l}\text { Forest Unit Porečke šume - weak intensity of the attack } \\
\text { Forest Unit Pecka bara and Forest Unit Štrbačko korito - weak intensity of the attack }\end{array}$}} \\
\hline 2011 & & & & & & & & & \\
\hline 2012 & 3783.0 & 8.6 & 13566.0 & 31.0 & 9239.0 & 21.1 & 17176.0 & 39.3 & 43764.0 \\
\hline 2013 & 0 & 0 & 4688.0 & 10.8 & 10839.0 & 24.9 & 27947.0 & 64.3 & 43474.0 \\
\hline
\end{tabular}

Based on the data stated in the Table 1 it is seen that the growth of the population level of the gypsy moth in the period 1996-1997 over the observed period did not acquire the typical form of outbreak.

The intensity of the attack was, to a great extent, in the category of weak and moderate ones. The mechanical and chemical controls measures that were taken in the egg instars, as well as the activity of the numerous natural enemies of the gypsy moth, most probably caused such a state and returned the population level of the gypsy moth to the normal value, when it does not cause the economic and ecological damages of the forest tree species.

The period of the latency of gypsy moth in this area lasted for five years, after which the outbreak of it occurred again year 2003), and which will acquire the all characteristics of the outbreak in the following year. The mechanical and chemical measures of the gypsy moth control in the egg instar, taken in the autumn and winter seasons, did not produce the satisfying results, since there was a great number of the egg masses hatched high on the stems and in the crowns. In the autumn of 2004 the newly-laid gypsy moth egg masses were reported on the area of 9992 hectares, and in 2005 on the area of 16767 hectares.

In the spring of 2006, at the area of 10000 hectares, the aerial spraying in the larval instar, by the chemical insecticide of the third generation - Dimilin SC48 (active ingredient diflubenzoron) was done. The control was efficient, so in the autumn of 2006 the newly-laid egg masses were not reported, and in the following year the new period of latency, which lasted for four years, occurred.

The third outbreak of the gypsy moth over the observed period also had all characteristics of the oubreak, but this time the attacked area was 2.6 times greater. The retrogradation phase occurred in the autumn of 2004, and it was the result of the effective aerial control of the gypsy moth in the larval instar by the microbiological preparation Foray 48B, at the area of 33,176 hectares, as well as of the increased activity of the natural enemies of the gypsy moth. It should be noted here that the above-mentioned preparations are highly selective and ecologically 
safe, and are applied in the ultra low volumes (ULV) (Tabaković-Tošić and Jovanović, 2007).

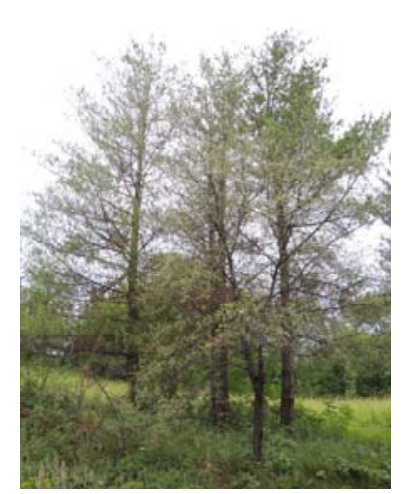

Picture 1

June 2013 - partial defoliation of individual trees

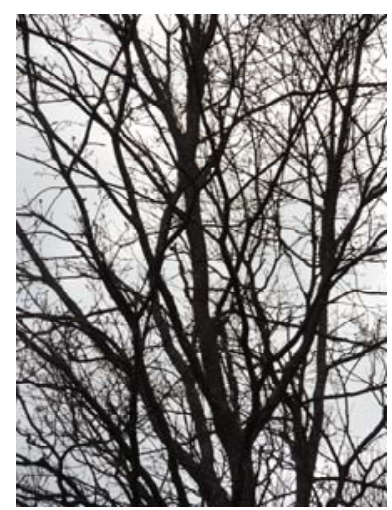

Picture 2

June 2013. - total

defoliation

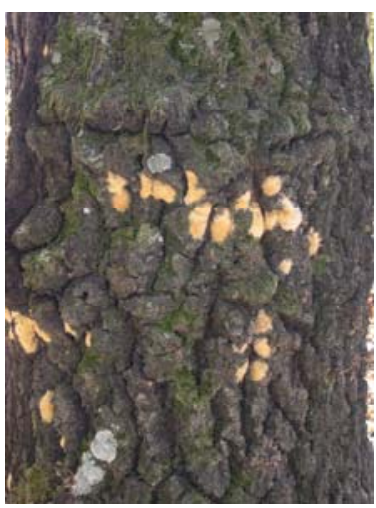

Picture 3

Septembar 2013. - newlylaid egg masses

In the observed period, in the Laboratory of the Institute of Forestry, the analysis of the gypsy moth egg masses, collected in the area of the National Park Đerdap (Table 2) was made on a yearly basis.

The average number of eggs in the egg mass ranged from 240.0 (year 2005 ) to 824.6 (year 2003). The percentage of the vital eggs in the total number of eggs ranged from 79.7 in 2013 to 99.7 in 2011 . The average level of parasitisation of the eggs ranged from 0 in 2011 to $19.8 \%$ u 2013. These leves of parasitisation should not be considered to be final, owning to the laboratory conditions of the treatment, where the activity of a series of parasites and predators, to which the egg masses were exposed in nature, was disabled.

Table 2 Laboratory analysis of the gypsy moth egg masses sampled from the represensentative semple plots in the area of the National Park Đerdap.

\begin{tabular}{|c|c|c|c|c|c|c|c|c|}
\hline \multirow{4}{*}{ Year } & \multirow{4}{*}{$\begin{array}{l}\text { The number } \\
\text { of egg masses }\end{array}$} & \multicolumn{7}{|c|}{ Average number of eggs in the egg masses } \\
\hline & & \multicolumn{4}{|c|}{ Fertilized } & \multirow{2}{*}{\multicolumn{2}{|c|}{ Unfertilized }} & \multirow{3}{*}{$\frac{\text { Total }}{\mathrm{N}}$} \\
\hline & & \multicolumn{2}{|c|}{ Vital } & \multicolumn{2}{|c|}{ Parasitized } & & & \\
\hline & & $\mathrm{N}$ & $\%$ & $\mathrm{~N}$ & $\%$ & $\mathrm{~N}$ & $\%$ & \\
\hline 1996 & 125 & 296.0 & 91.5 & 9.0 & 2.8 & 18.5 & 5.7 & 323.5 \\
\hline 1997 & 245 & 329.9 & 95.9 & 7.8 & 2.3 & 6.4 & 1.8 & 344.1 \\
\hline \multicolumn{9}{|c|}{ 1997-2002 latency period for the gypsy moth } \\
\hline 2003 & 100 & 806.0 & 97.8 & 15.3 & 1.8 & 3.3 & 0.4 & 824.6 \\
\hline 2004 & 150 & 497.0 & 88.6 & 62.0 & 11.1 & 2.0 & 0.3 & 561.0 \\
\hline 2005 & 150 & 201.7 & 84.0 & 33.7 & 14.0 & 4.6 & 2.0 & 240.0 \\
\hline \multicolumn{9}{|c|}{ 2006-2008 latency period for the gypsy moth } \\
\hline 2010 & 80 & 554.1 & 94.6 & 29.3 & 5.0 & 2.4 & 0.4 & 585.8 \\
\hline 2011 & 150 & 537.9 & 99.7 & 0 & 0 & 1.7 & 0.3 & 539.6 \\
\hline 2012 & 350 & 608.6 & 97.7 & 14.2 & 2.0 & 1.9 & $\begin{array}{ll}0.3 \\
\end{array}$ & 624.7 \\
\hline 2013 & 658 & 483.0 & 79.7 & 118.0 & 19.8 & 3 & 0.5 & 604.0 \\
\hline
\end{tabular}

The results of the analysed quantitative and qualitative parameters of the gypsy moth egg masses confirm the above claim that in the forest area of the 
National Park Đerdap, over the period 1996-2014, the outbreak of the population level of the gypsy moth occurred three times.

The dynamics of the hatching of imagos from the previosly analysed egg masses was monitored in the special experiments. Every year only two species of egg parasites Anastatus japonicus Ashmead (syn. A. disparis Ruschka) and Oencyrtus kuwanae (Howard) were present. Every year the ratio of them was relatively equal: $30: 70 \%$, with the clear dominance of $O$. kuwanae.

In the spring of 2012, 2013 and 2014 at some sample plots in the oak and beech forests, the increased mortality rate of the younger and older larval instars in comparison with the expected one was reported. Logically, the following question was posed: What has been killing them? In order to get the answer to this question, the detailed analysis of the possible causes was conducted.

By the detailed study of the dead gypsy moth larvae, two groups of the characteristic symptoms were reported: first - caused by E. maimaiga, and second caused by the $L d M N P V$.

During the field research clear symptoms of a disease caused by baculovirus $L d M N P V$ were observed in 5.5 (2012), 13.5 (2013) and 20.1 (2014) percent of the dead larvae. Clear and characteric symtoms of the fungal diseases caused by E. maimaiga were at 94.5 (2012), 86.5 (2013) and 79.9 (2014) percent of the reported dead gypsy moth larvae.

By the laboratory studies of the causes of the mortality of the gypsy moth larval instars and by the microscopic analysis of the dead caterpillars, the presence of $L d M N P V$ occlusion bodies and the conidiospores and azigospores of the entomopathogenic fungus E. maimaiga was confirmed, but the presence of $L d M N P V$ was reported only in the dead older caterpillars $\left(\mathrm{L}_{4}-\mathrm{L}_{6}\right)$. The reason of such a relation of two studied pathogens lies in the fact that the fungus is active at low, as well as high, gypsy moth population levels. This sets it apart from natural controls such as the $L d M N P V$, a viral disease of gypsy moth which kills caterpillars under stress from high population densities and diminishing food supplies. Research also shows indications of a strong synergistic relation between them.

\section{Acknowledgements:}

The study was partly financed by the Ministry of Science of the Republic of Serbia, the Project 31070-SUBPROJECT: New technological methods in the integral protection of forests with the focus on the entomopathogenic fungus Entomophaga maimaiga, as the possible solution to the problem of the frequent occurrences of the outbreak of gypsy moth in the forest ecosystems of Serbia.

\section{REFERENCES}

Marinković, P. (1992) Desiccation of the Sessile Oak in Northeastern Serbia - Causes and Consequences. In: Epidemic Desiccation of the Sessile Oak in Northestern Serbia, Collection of Papers on the occasion of the conference.

Medarević M., (2001): Forests of Đerdap. The National Park Đerdap and Ecolibri, Belgrade. 
Milanović, S., Tabaković-Tošić, M. Marković, N. (2006): Effect of Host Plant on Gypsy Moth Diet and Biological Efficacy of Btk Preparations. Bulletin of the Faculty of Forestry, Belgrade, 94: 197-210.

Stanković, S. (2003): National Park Đerdap - The Đerdap National Park, Bulletin of the Serbian Geographical Society, 83(1): 43-56.

Stevanović, V. (1996): Autochthonous Botanical Garden. In: National Park Đerdap - Time Immemorial of Nature and Mankind, Belgrade: Ecolibri, 72-83

Tabaković-Tošić, M. (2005 - 2006): Major Factor for Successful Application of Commercial Bacillus thuringiensis var. kurstaki against Gypsy Moth Outbreaks in Forests. Proceedings of $25^{\text {th }}$ Jubilee Assembly of East Palearctic Regional Section - International Organisation for Biological Control of Noxious Animals and Plants (IOBC), p. 185-189, also published in "Бюллетен № 6 - Постоянной Комиссии по биологической зашите леса "БИОЛОГИЧЕСКАЯ ЗАШИТА ЛЕСА: НАПРАВЛЕНИЯ И ПУТИ РАЗВИТИЯ", Budapest - Пушкино, Hungary - Russian Federation, 132-136.

Tabaković-Tošić, M. (2011): Gypsy Moth Predators, Parasites and Pathogens in Belgrade Forests in the Period 2010-2011. Suistainable Forestry, 63-64.

Tabaković-Tošić, M. (2012): Gypsy Moth, Lymantria dispar (L.), and Its Natural Enemies in the Forests of Central Serbia. - Suistainable Forestry, 65-66, 133-148.

Tabaković-Tošić M., Georgiev, G., Mirchev, P., Tošić, D. \& Golubović-Ćurguz, V. (2013). Gypsy Moth in Central Serbia over the Previous Fifty Years. - Acta Zoologica Bulgarica, 65(2), 165-171.

Tabaković-Tošić, M., Jovanović, V. (2007): Gypsy Moth (Lymantria dispar L.) Outbreaks in the Republic of Serbia 2003-2005. - Plant Protection, 17: 213-224, Skopje.

\title{
THE OUTBREAKS OF THE GYPSY MORH IN FOREST PLANTATIONS OF THE NATIONAL PARK ĐERDAP IN THE PERIOD FROM 1996 TO 2014
}

\author{
Mara TABAKOVIĆ-TOŠIĆ, Marija MILOSAVLJEVIĆ, Nemanja SIMOVIĆ
}

\section{Summary}

In the area of the National Park Đerdap, after the thirty-year period of latency, the significant growth of the gypsy moth population level occurred three times. The growth of the population level of the gypsy moth in the period 1996-1997 did not acquire the typical form of outbreak. The intensity of the attack was, to a great extent, in the category of weak and moderate ones.

The mechanical and chemical controls measures that were taken in the egg instars, as well as the activity of the numerous natural enemies of the gypsy moth, most probably caused such a state and returned the population level of the gypsy moth to the normal value, when it does not cause the economic and ecological damages of the forest tree species.

The period of the latency of gypsy moth in this area lasted for five years, after which the outbreak of it occurred again (year 2003), and which will acquire the all characteristics of the outbreak in the following year.

The mechanical and chemical measures of the gypsy moth control in the egg instar, taken in the autumn and winter seasons, did not produce the satisfying results, since there was a great number of the egg masses hatched high on the stems and in the crowns. 
In the autumn of 2004 the newly-laid gypsy moth egg masses were reported on the area of 9,992 hectares, and in 2005 on the area of 16,767 hectares. In the spring of 2006, at the area of 10,000 hectares, the aerial spraying in the larval instar, by the chemical insecticide of the third generation - Dimilin SC48 (active ingredient diflubenzoron) was done. The control was efficient, so in the autumn of 2006 the newly-laid egg masses were not reported, and in the following year the new period of latency, which lasted for four years, occurred. The third outbreak of the gypsy moth over the observed period also had all characteristics of the oubreak, but this time the attacked area was 2.6 times greater. The retrogradation phase occurred in the autumn of 2004, and it was the result of the effective aerial control of the gypsy moth in the larval instar by the microbiological preparation Foray $48 \mathrm{~B}$, at the area of 33,176 hectares, as well as of the increased activity of the natural enemies of the gypsy moth.

In the observed period, in the Laboratory of the Institute of Forestry, the analysis of the gypsy moth egg masses, collected in the area of the National Park Đerdap (Table 2) was made on a yearly basis. The average number of eggs in the egg mass ranged from 240.0 (year 2005) to 824.6 (year 2003). The percentage of the vital eggs in the total number of eggs ranged from 79.7 in 2013 to 99.7 in 2011 . The average level of parasitisation of the eggs ranged from 0 in 2011 to $19.8 \% \mathrm{u} 2013$. These leves of parasitisation should not be considered to be final, owning to the laboratory conditions of the treatment, where the activity of a series of parasites and predators, to which the egg masses were exposed in nature, was disabled.

The results of the analysed quantitative and qualitative parameters of the gypsy moth egg masses confirm the above claim that in the forest area of the National Park Đerdap, over the period 1996-2014, the outbreak of the population level of the gypsy moth occurred three times.

The dynamics of the hatching of imagos from the previosly analysed egg masses was monitored in the special experiments. Every year only two species of egg parasites Anastatus japonicus Ashmead (syn. A. disparis Ruschka) and Oencyrtus kuwanae (Howard) were present. Every year the ratio of them was relatively equal: 30:70\%, with the clear dominance of $O$. kuwanae.

In the spring of 2012, 2013 and 2014 at some sample plots in the oak and beech forests, the increased mortality rate of the larvae were reported and analyzed. During the field research clear symptoms of disease caused by baculovirus $L d M P N V$ and characteristic symptoms of the fungal diseases caused by E. maimaiga were found on dead gypsy moth caterpillars.

By the laboratory studies of the causes of the mortality of the gypsy moth larval instars and by the microscopic analysis of the dead caterpillars, the presence of $L d M N P V$ occlusion bodies and the conidiospores and azigospores of the entomopathogenic fungus $E$. maimaiga was confirmed, but the presence of $L d M N P V$ was reported only in the dead older caterpillars $\left(\mathrm{L}_{4}-\mathrm{L}_{6}\right)$. The reason of such a relation of two studied pathogens lies in the fact that the fungus is active at low, as well as high, gypsy moth population levels. This sets it apart from natural controls such as the $L d M N P V$, a viral disease of gypsy moth which kills caterpillars under stress from high population densities and diminishing food supplies. Research also shows indications of a strong synergistic relation between them. 


\title{
PRENAMNOŽENJA GUBARA U ŠUMSKIM KOMPLEKSIMA NACIONALNOG PARKA ĐERDAP U PERIODU OD 1996. DO 2014. GODINE
}

\author{
Mara TABAKOVIĆ-TOŠIĆ, Marija MILOSAVLJEVIĆ, Nemanja SIMOVIĆ
}

\section{Rezime}

U području Nacionalnog parka Đerdap, nakon tridesetogodišnjeg latentnog perioda, tri puta je došlo do značajnog povećanja populacionog nivoa gubara.

Povećanje populacionog nivoa gubara u 1996-1997. godini nije poprimilo tipičan karakter gradacije. Intenzitet napada je najvećim delom, bio u kategoriji slabog i srednjeg. Preduzete mehaničke i hemijske mere suzbijanja u stadijumu jajeta, kao i delovanje brojnih prirodnih neprijatelje gubara, su najverovatnije uzrokovale ovakvo stanje i vratile populacioni nivo gubara na normalnu vrednost, kada ne pričinjava ekonoske i ekološke štete šumskim vrstama drveća.

Period latence gubara u ovom području je trajao pet godina, nakon čega ponovo nastupa njegovo prenamnoženje (2003. godina), a koje će u narednim gidinama poprimiti sve osobine gradacije. Mehaničke i hemijske mere suzbijanja gubara u stadijumu jajeta, preduzete u jesenjem i zimskom periodu 2003., 2004. i 2005. godine, nisu dale zadovoljavajuće rezultate, jer se radilo o velikom broju legala položenih visoko na deblima i u krošnjama. U jesen 2004. godine novopoloženih jajnih legala gubara je bilo na ukupnoj površini od 9.992 ha, a 2005. na 16.767 ha. U proleće 2006. godine, na površini od 10.000 ha, preduzeto je aviosuzbijanje u stadijumu larve, hemijskim insekticidom treće generacije Dimilinom SC48 (aktivna materija diflubenzuron). Suzbijanje je bilo efikasno, pa u jesen 2006. nisu primećena novopoložena jajna legla, odnosno, u narednoj godini nastupio je novi latentni period u trajanju od četiri godine.

Treće prenamnoženje gubara $u$ istraživačkom periodu takođe ima sve osobine gradacije, s tim što je ovaj put napadnuta površina 2,6 puta veća. Retrogradaciona faza je nastupila u jesen 2014. godine, a posledica je uspešnog aviosuzbijanja gubara u stadijumu larve mikrobiološkim preparatom Foray 48B, na površini od 33.176 ha, kao i povećanom aktivnošću prirodnih neprijatelja gubara.

U istraživačkom periodu, u laboratoriji Instituta za šumarstvo, svake godine je obavljana analiza jajnih legala gubara prikupljenih u području Nacionalnog parka Đerdap (Tabela 2). Prosečan broj jaja u leglu se kretao od 240.0 (2005. godina) do 824.6 (2003. godina). Procentualno učešće vitalnih u ukupnom broju jaja prosečno iznosi od $79.7 \mathrm{u}$ 2013. do 99.7 u 2011. godini. Prosečna parazitiranost jaja kretala se od 0 u 2011. godini, do $19,8 \%$ u 2013. Ove vrednosti parazitiranosti ne treba shvatiti kao konačne jer se tu radi o laboratorijskim uslovima držanja, gde je onemogućeno delovanje niza parazita i predatora kojima su legla izložena u prirodi. Rezultati analiziranih kvalitativnih i kvantitativnih parametara jajnih legala gubara potvrđuju prethodno navedenu tvrdnju da je u šumskom području Nacionalnog parka Đerdap, u periodu od 1996-2014. godine, tri puta došlo do gradogenog povećanja populacionih nivoa gubara.

Dinamika izletanja imaga parazita iz prethodno analiziranih jajnih legala, praćena je u posebnim ogledima. Svake godine su bile prisutne samo dve vrste jajnih parazita Anastatus japonicus Ashmead (syn. A. disparis Ruschka) i Oencyrtus kuwanae (Howard). Svake godine njihov procentualni odnos bio je relativno ujednačen 30:70\%, uz jasnu dominaciju $O$. kuwanae.

U proleće 2012., 2013. i 2014. godine, na pojedinim oglednim površinama u hrastovim i bukovim šumama, uočena je značajno povećana smrtnost larvi gubara, pa su obavljena intenzivna proučavanja mogućih uzroka. U toku terenskih istraživanja, jasni 
simptomi oboljenja izazvanih delovanjem bakulovirusa $L d M P N V$ i entomopatogene gljive E. maimaiga, konstatovani su kod uginulih gusenica gubara.

Laboratorijskim istraživanjima uzroka smrtnosti larvenih stupnjeva gubara, i mikroskopskom analizom uginulih gusenica, dokazano je prisustvo okluzivnih tela $L d M N P V$, te konidija i azigospora entomopatogene gljive $E$. maimaiga, s tim što je pozitivan nalaz $L d M N P V$ bio jedino kod starijih gusenica $\left(\mathrm{L}_{4}-\mathrm{L}_{6}\right)$. Objašnjenje ovakvog odnosa dva istraživana patogena leži u činjenici da je gljiva aktivna uvek, i pri niskom i pri visokom populacionom nivou gubara, dok je $L d M N P V$ aktivan samo pri velikoj populacionoj gustini domaćina, odnosno kada su gusenice pod stresom usled nedostatka hrane. Takođe, ova istraživanja pokazuju naznake snažnog sinergetskog odnosa između ova dva entomopatogena. 